\title{
Exchange Rate Volatility and Macroeconomic Performance in Hong Kong.
}

\author{
May 2000 \\ Mark Crosby, \\ Department of Economics, \\ University of Melbourne, \\ Parkville, 3010, Australia. \\ and \\ Hong Kong Institute for Monetary Research.
}

\begin{abstract}
In this paper evidence on whether Hong Kong's currency board arrangement, in place since 1983, has affected the volatility of real macroeconomic variables is presented. Simple evidence on the relative volatilities of relevant macroeconomic variables pre and post 1983 is presented, before a more formal econometric framework is utilised to examine the linkages between the exchange rate and the real economy. It is found that the currency board period has been one of relative stability in Hong Kong, though it has also been a period where external factors have been relatively benign. Even after controlling for the external environment it is found that the currency board period is one of low macroeconomic volatility.
\end{abstract}

This paper was written while the author was visiting the Hong Kong Institute for Monetary Research during the first half of 2000. The author thanks the HKIMR for their hospitality, Emily Cheng and Paul Lam for research assistance, and comments from seminar participants at the HKIMR which have greatly improved this paper. The views presented in this paper are those of the author and do not necessarily reflect those of the Hong Kong Institute for Monetary Research, its Council of Advisors, or Board of Directors. 


\section{Introduction}

The Asian crisis has focused attention on the real costs that fixed exchange rates can lead to when a country is forced to realign or float a misaligned exchange rate. The simplest way to avoid such costly realignments is to have a flexible exchange rate, and so it can be argued that flexible exchange rates should reduce real volatility in an economy. Yet flexible exchange rates have costs of their own. Nominal and real exchange rate volatility under flexible exchange rates are much larger than volatility in fundamentals. Such volatility may translate into reduced trade and economic growth. In this paper an attempt at assessing the impact of Hong Kong's fixed exchange rate on real volatility in Hong Kong is made.

Hong Kong has adopted a number of different exchange rate regimes in its history, twice adopting currency board systems. ${ }_{\text {From }} 1935$ to 1973 , with the exception of the years of Japanese occupation, Hong Kong operated a sterling exchange system - a currency board with note issue back by holdings of Sterling assets. After briefly pegging the Hong Kong dollar to the United States dollar in 1972, it was decided to float the exchange rate on November 24 1974. After a period of political uncertainty following the 1982 decision by China to resume sovereignty over the entirety of Hong Kong (instead of just the New Territories), and a steep fall in the exchange rate throughout 1983, the government announced on October 151983 that a currency board would be reinstated. Since this time the exchange rate has remained fixed at the rate of US\$1 = HK\$7.8. Under the currency board arrangement note issuing banks are required to pay US dollars to the Exchange Fund in exchange for Certificates of Indebtedness, as cover for banknotes issued.

\footnotetext{
${ }^{1}$ For a detailed description of Hong Kong's experience under the currency boards see Jao (1998).
} 
The Hong Kong experience provides an interesting example for research on the effects of exchange rate regime on a macroeconomy. Having survived the numerous currency crises of the 1990s, Hong Kong's experience with a fixed exchange rate is long-lived by modern standards. While the currency board system is more likely to remain in operation because of the more rule based monetary policy that is required when compared with other fixed exchange rate systems, it is of interest to examine whether these rules provide the macroeconomy with additional benefits or costs.

The paper will proceed as follows. In the following section the existing theoretical and empirical evidence on the impact of exchange rate volatility on trade and macroeconomic performance will be briefly outlined. Section 3 presents evidence on the volatilities of a number of macroeconomic variables relevant to Hong Kong's economic performance. Section 4 presents formal evidence trying to link together these volatilities, and the final section offers some concluding comments.

\section{Existing Evidence on Exchange Rate Volatility and \\ Macroeconomic Performance.}

\section{Theoretical Evidence}

There are two strands of macroeconomic theory that relate to the question of how exchange rate volatility affects macroeconomic performance. The first strand examines how the domestic economy responds to foreign and domestic real and monetary shocks under different exchange rate regimes. The second strand focuses on 
the issue of how exchange rate volatility under flexible exchange rate regimes affects international trade.

Macroeconomic theory suggests that the appropriate exchange rate regime depends on the types of shocks that an economy typically faces, and on the extent to which capital is internationally mobile. In the case of free mobility of capital, an economy that is affected mainly by shocks to the LM curve, due to changes in money demand for example, will experience large fluctuations in output, inflation, and the exchange rate if the exchange rate is flexible. If the exchange rate is fixed and capital is internationally mobile then the money supply is endogenous - changes in money demand determine changes in the money supply so that LM shocks will have no effect on output or inflation.

A foreign real shock will have larger affects on the domestic economy if the exchange rate is fixed. If, for example, foreign income falls, the demand for domestic exports will fall, leading to a fall in domestic income. Under flexible exchange rates this effect will be mitigated by a depreciation of the exchange rate. A foreign financial shock will have opposite effects under fixed and flexible exchange rates. A rise in foreign interest rates will lead to a depreciation and a rise in income under flexible exchange rates, but will lead to a monetary contraction and a fall income under fixed exchange rates.

Overall, the impact of the exchange rate regime on volatility will depend on the type of shocks hitting the domestic economy, with the general principle being that flexible exchange rates provide better insulation against foreign sourced real shocks, and fixed 
exchange rates insulating against domestic sourced LM type shocks. In relation to this final point, it is also true that fixed exchange rates are thought to deliver more credible monetary policy and lower inflation. To the extent that lower inflation reduces inflation variability then a fixed exchange rate regime will be preferable.

There is also a very large literature examining the question of how the exchange rate regime affects international trade. The general argument is that exchange rates (both real and nominal) will be more variable under flexible than under fixed exchange rates, and this volatility will be harmful to trade.$^{2}$ Trade will be worse affected the more risk averse are firms, the fewer are the opportunities to hedge against exchange rate fluctuations, and the greater is the fraction of revenues and expenditures denominated in foreign currency.

An interesting strand of this literature focuses on the impact of exchange rate variability on firms' location decisions. When deciding whether or not to invest in a foreign country, the variability of the exchange rate will affect the option value of delaying investment. Greater exchange rate variability will lead to 'hysteresis', whereby firms are locked out of foreign countries by exchange rate variability, or locked into countries in which firms are already located. It is hard to gauge the overall effect of hysteresis on trade volumes, though it would appear that hysteresis would reduce the level of capital flows between countries. In this paper some time series evidence on the impact of exchange rate volatility on trade in Hong Kong will be presented.

\footnotetext{
${ }^{2}$ For a survey of both the theoretical and the empirical literature see Côté.
} 


\section{Empirical Evidence}

Much of the research examining the relationship between exchange rate regimes and real volatility has been a byproduct of empirical research on purchasing power parity. A very large literature has arisen documenting the fact that flexible exchange rates lead to medium to high frequency movements in real and nominal exchange rates that are too great to be explained by macroeconomic fundamentals. ${ }^{3}$ However, a number of papers focus more directly on the implications of this volatility for the real economy.

Baxter and Stockman (1989) investigate the time series behaviour of a number of macroeconomic aggregates under alternative exchange rate systems during the postwar period. They use a sample of 49 countries, and find little evidence of any differences in the behaviour of macroeconomic aggregates or trade flows under alternative exchange rate systems. Given that the flexible exchange rate periods studied in their paper were periods of high exchange rate volatility, the conclusion could be drawn that exchange rate volatility did not affect macroeconomic behaviour in the large cross section of countries considered. Baxter and Stockman removed the trends in the series under consideration by applying a linear trend, or by first differencing. They then examine the properties of the detrended data, implicitly focusing on the high and medium frequencies when the linearly detrended data is examined, while focusing on the higher frequency properties of the (quarterly) data when the differenced data are considered.

\footnotetext{
${ }^{3}$ For a detailed survey of this literature see Froot and Rogoff (1995).
} 
Flood and Rose (1995) examine the bilateral \$US exchange rate and macroeconomic fundamentals in the G7 countries plus Holland and Sweden, over the period 1975 to 1990. They find that the monthly volatility of the nominal exchange rate cannot be explained by any usual set of macroeconomic fundamentals. They first compute the sample standard deviations of each of the variables for non-overlapping two year subsamples of the data, which generates eight sample periods for each of the nine countries. Volatilities of the macroeconomic variables can then be compared with the volatility of the real exchange rate. The only robust correlation among the bivariate comparisons of the volatilities appears to be a negative correlation between real output volatility and exchange rate volatility. The paper also considers some well known structural models to try to explain the exchange rate volatility, but is unable to find any convincing explanation for the rise in volatility that occurs when exchange rates are flexible. They tentatively conclude that there is "little empirical evidence that reducing exchange rate volatility compromises the stability of other macroeconomic variables."

Rose (1996) examines a larger data set of twenty industrialised countries and considers the question of whether fixed exchange rates "bottle up" volatility, which is released when the exchange rate is floated or devalued. The volatility of macroeconomic variables three years prior to and three years after floats and devaluations is examined for evidence of changes in volatility. It is found that exports and the current account become more variable after such episodes, though other macroeconomic aggregates do not. Once again the conclusion is that there is little evidence of significant increases in volatility due to changes in the exchange rate regime. 
Three papers that take a time series perspective on the question of exchange rate volatilities and macroeconomic behaviour are Hutchison and Walsh (1992), Bayoumi and Eichengreen (1994) and Kwan and Lui (1999). Hutchison and Walsh look at the performance of the Japanese economy before and after the move to flexible exchange rates in the mid-1970s. They find that output was much more stable after the move to flexible exchange rates, but they attribute this to both a more industrialised economy in Japan, and also to a more benign internal economic environment after the mid1970s. Hutchison and Walsh use structural VARs to decompose output into shocks attributable to foreign disturbances (US GNP and money supply variables), to oil price shocks, and to domestic disturbances (Japanese GNP shocks). They find that there was a change in both the magnitude and the nature of shocks hitting the Japanese economy after 1973. After 1973 real oil shocks were larger, but domestic sourced shocks were much smaller. Impulse responses are consistent with the flexible exchange rate regime insulating the domestic economy from foreign shocks - impulse responses for oil price shocks suggest a much smaller output response during the flexible rate period. Overall, they conclude that the transition to a more mature economy reduced the size of domestic sourced shocks in Japan, and that the economy was more stable after the move to flexible exchange rates despite larger oil and US monetary shocks after 1973. In addition they conclude that their impulse responses suggest that flexible exchange rates in Japan are more effective in insulating Japanese real output from foreign shocks.

Bayoumi and Eichengreen (1994) use a bivariate SVAR in prices and output to examine the aggregate demand and supply equations for the G7 countries. They use the assumption that demand shocks do not have permanent effects to identify their 
model (along the lines of Blanchard and Quah (1989)), and estimate the model over the pre and post Bretton Woods eras. Using the impulse response patterns from the estimated model, they argue that the aggregate demand curve has become steeper for the G7 countries over the floating rate period, a result they attribute to the difference in monetary policy practices under floating rates. The implication of a steeper aggregate demand curve is that supply shocks have a smaller impact on output (or output growth).

Kwan and Lui (1999) estimate the model used by Bayoumi and Eichengreen on the Hong Kong data, and reach the opposite conclusion to Hutchison and Walsh - they find that the currency board in Hong Kong reduced output and inflation volatility after 1983. Both output and inflation volatility fell after 1983, and Kwan and Lui attribute two-thirds of the fall in volatility to the introduction of the currency board. The variables in their model are Hong Kong GDP and prices. The choice of only two variables in their model may be problematic in that their structure would not adequately capture changes in Hong Kong's external environment such as those changes found for Japan by Hutchison and Walsh. In other words, their results could be driven by a change in the size of foreign shocks after 1983, not captured by the model, rather than by a change in the exchange rate regime. It is of interest that the papers considered above reach three different conclusions regarding the effect of the exchange rate regime on the macroeconomic environment. In the first case the exchange rate regime did not affect macroeconomic outcomes, in two cases flexible exchange rates reduced volatility, while in the final case flexible exchange rates increased volatility. It would seem that there is thus considerable scope for more research in this area. 
There is also a very large literature that examines the impact of exchange rate volatility on trade. The predominant finding in the literature is that exchange rate volatility either has no effect, or has a very small effect, on trade. Gagnon (1993) seeks to explain this result using a calibrated model designed to exaggerate the effects of exchange rate variability on trade. He finds that exchange rate volatility of the magnitudes observed until the early 1990s would not significantly affect trade.

Two recent papers that do find significant effects of exchange rate volatility on trade are Rose (1999) and Arize, Osango and Slottje (2000). Rose finds a very large positive effect of a currency union on international trade, and a small negative effect of exchange rate volatility on trade. Rose uses a large panel data set to estimate an augmented gravity model of trade. Standard gravity models include only income and distance variables to explain trade between two countries - the model Rose estimates is augmented with a number of other variables including common language, common currency, and exchange rate volatility.

Arize, Osango and Slottje (2000) estimate an export demand equation for thirteen LDCs with world demand conditions, the terms of trade, and the moving sample standard deviation of the exchange rate as explanatory variables. In all countries the impact of exchange rate volatility on trade is found to be negative and significant.

Overall the empirical literature does not seem to come to any firm conclusion about the implications of greater exchange rate volatility on trade. However, there do appear to be some important gaps in our understanding of the possible effects of exchange rate volatility. Firstly, there is very little time series evidence on exchange rate 
volatility and macroeconomic volatility. Secondly, it is of interest to consider the behaviour of the Hong Kong economy during the currency board period, as this type of fixed exchange rate regime remains relatively uncommon. A number of countries have recently implemented a currency board, and so a more detailed understanding of the Hong Kong experience will better enable a judgement on the costs and benefits of such an arrangement. In the next section of the paper the univariate properties of the data are outlined.

\section{Volatility in Hong Kong}

In this section of the paper the time series properties of a number of macroeconomic series relevant to Hong Kong's economic performance will be summarised. The variables that are examined are Hong Kong GDP, government expenditure, exports, imports (all real), the CPI, the (CPI based) real exchange rate, the US Federal Funds rate, the real (Hong Kong dollar) price of oil, and Singaporean real GDP. ${ }^{\text {In }}$ In this section of the paper the univariate properties of the data are documented, while in the next section we attempt to relate the variables to try and determine any effects that real exchange rate volatility has on GDP and trade. Factors that might affect GDP and trade include fiscal policy (government expenditure), exchange rates, and variables reflecting foreign monetary and real forces (the Funds Rate and oil prices). Singaporean GDP data is presented because of the frequent comparisons made between the two countries. The fact that Singapore had a flexible exchange rate over

\footnotetext{
${ }^{4}$ The real exchange rate was constructed using the trade weights of Hong Kong's six largest trading partners excluding China (the US, Japan, Korea, Taiwan, Germany and the UK). The trade weights used were those used by the IMF to construct a real exchange rate series for Hong Kong. (For details on the construction of the weights see Zanello and Desruelle (1997)). China was not included because a quarterly CPI series was unavailable over the sample period used. A large fraction of Hong Kong's
} 
the sample period makes this comparison of interest to this paper. All data is quarterly, seasonally adjusted, from 1974:3 to 1999:4.

Figure 1 presents the graphs of the growth rates of each of the variables. ${ }^{\mathrm{E}}$ The graph of Hong Kong GDP growth shows quite clearly a fall in volatility at the end of the sample. However, the fall in volatility appears to begin around 1989, six years after the introduction of the currency board. Government expenditure, export, and import growth shows no obvious pattern in volatility, though exports and imports do appear to be quite volatile prior to 1976 . Changes in inflation show much less volatility since around the time of the introduction of the currency board in 1983. Changes in the real Hong Kong dollar price of oil are on average large and contain some spikes, though there is no obvious volatility pattern. Movements in the Federal Funds rate have, however, showed considerably less volatility since 1983 than previously. It is interesting that this decline in volatility corresponds quite closely with the introduction of the currency board. Real exchange rate changes and Singaporean GDP growth show no obvious patterns in volatility, though it appears that real exchange rate volatility may be lower in the 1990s than prior to this.

The upper half of Table 1 provides some more formal evidence on the volatilities of each of the variables prior to and since 1983. The quarterly growth rates for each of the series is presented, along with the standard deviation and correlation with GDP over the fixed and the floating rate period (the fourth quarter of 1983 was omitted as

trade with China is re-exports, which are not as closely related to the real exchange rate as other forms of trade, and so this omission is not seen to be too important.

${ }^{5}$ Augmented Dickey-Fuller tests for unit roots (including a constant or a constant and a trend and up to four lags) suggest that all of the variables are I(1), with the exception of the CPI, which appears to be $\mathrm{I}(2)$. Hence all of the growth rates reported, with the exception of the inflation rate, will be stationary over the sample. Results of the unit root tests are available from the author on request. 
the exchange rate was fixed during this quarter). Output growth is lower over the latter sub-sample, though not significantly so. Output growth is also lower in Singapore, perhaps reflecting both countries 'catch-up' with high income industrialised countries. The only variables with significantly different means over the sub-samples are government expenditure growth and the price level (inflation) with lower growth, and the real exchange rate with significantly higher growth. ${ }^{6}$ While it might be argued that the lower output growth could be related to the real exchange rate appreciation over the fixed exchange rate period, the IMF (1999) suggest that the appreciation is consistent with productivity growth and terms of trade movements over this period. It is noted that Singapore also experienced a large real appreciation over this seventeen year period.

The variances of the differenced data tell a very systematic story. With the exception of the change in oil prices and Singaporean GDP growth, all of the variances are lower. Only in the case of inflation and the real exchange rate is this reduction in volatility insignificant. It is interesting to note that the fixing of the exchange rate did not result in a significant fall in real exchange rate volatility. If Hong Kong had the same real exchange rate weights as the US then fixing the exchange rate to the US dollar will simply buy Hong Kong the real exchange rate volatility of the US. The extent to which the currency board regime will reduce real exchange rate volatility will depend on the importance of the US in Hong Kong's trading relationships. Two

\footnotetext{
${ }^{6}$ Tests for the equality of means, variances and correlations rely on independent samples. Serial correlation may therefore be problematic to these tests. Autocorrelations are significant in the flexible rate period only for Singaporean GDP (first order) and inflation and its change (up to fourth order). In the fixed rate period there is evidence of first order serial correlation in GDP growth, second order serial correlation in export and import growth, and fourth order serial correlation in inflation.

${ }^{7}$ It is noted that the oil price data begins in 1974:3, just after the large OPEC related increase in prices. Adding two earlier data points would raise the variance of oil price inflation in the earlier period above that in the second period. (This would be true for any reasonable assumption about inflation in 1973/4. Actual quarterly CPI data does not exist before 1974:3).
} 
important facts relevant to the reduction in output volatility are the reduced variability in government expenditure growth and in the Federal Funds rate.

Correlations with GDP also show some changes over the two sub-samples. Government expenditure growth is acyclical, though the change in the correlation is significantly different from zero. Imports are acyclical in the flexible exchange rate period, but procyclical in the fixed rate period. Inflation is also acyclical, though the change from negative to positive correlation with GDP is significant. The Federal Funds rate switches from being countercyclical before 1984 to having a small positive correlation in the second sub-period. There are a number of stories consistent with this change, but an interesting possibility is that the Hong Kong economy (or at least Hong Kong monetary policy) has become more synchronised with that of the United States. If Hong Kong GDP growth were highly correlated with US GDP growth we might expect to see US tightenings during periods of high growth (and hence a positive correlation). The change to a positive correlation could be due to synchronisation of policy synchronising business cycles in the two countries, or due to synchronisation of the two countries' business cycles leading to synchronisation of policies. With a fixed exchange rate the first argument is likely to be correct, while the second argument may or may not be true. Finally, the change in the real exchange rate is acyclical.

It is possible that many of the 'facts' described in the upper half of Table 1 are related to the high frequency movements in the series, which may in some cases include a considerable amount of noise. In particular, we might think of high frequency movements in exchange rates, such as quarterly or monthly growth rates, as being dominated by short term fluctuations that are reversed over longer periods of time 
when fundamentals come to the fore. If this is the case then the focus on high frequency volatilities and correlations might give a misleading impression of the business cycle characteristics of the variables. The volatilities and correlations reported in the lower half of Table 1 refer to data that have had the high frequency components and the trends filtered from the data. A band pass filter, described in Baxter and King (1995), is used to remove the trends and the high frequency variability in the series ${ }^{\mathbb{B}}$. After filtering, the movements in each series that persist for more than eighteen months and less than eight years remain (commonly described as being the business cycle components of the series). Since we are interested in the effects of exchange rates on the real economy it would seem that these might be important frequencies on which to focus attention. The empirical literature on exchange rate behaviour (see Froot and Rogoff (1995) for example) is consistent with departures from PPP having a half-life of three to five years. In other words shocks to the real exchange rate on average take about six to ten years to be seventy-five percent dissipated. Any long run trends in real exchange rates, if they exist, will therefore reflect differences in productivity across countries rather than short run shocks to the real exchange rate. Hence filtered movements in the real exchange rate will reflect persistent movements in the real exchange rate not associated with trends that are related to the structure of the economy, but which may have important effects on the real economy.

Figures 11 to 18 show the filtered data for GDP (the solid line), along with each of the other series under consideration. A number of features of the data are clear from the

\footnotetext{
${ }^{8}$ Baxter and King (1995) compare this filter to the Hodrick-Prescott filter and some other detrending methods in some detail. The band pass filter renders any I(1) or I(2) series stationary. The filter leaves components in a series that are similar to those obtained using the HP filter, though an important advantage over the HP filter is the fact that no phase shifts in the filtered series are induced.
} 
graphs. Both imports and exports are strongly procyclical. The real exchange rate and GDP do not appear to be closely related, oil price swings are large, and the business cycle in Hong Kong is not closely related to the Singaporean business cycle (except that both countries seem to be in recession together).

The lower half of Table 1 presents the standard deviations and correlations with GDP for the filtered data. During the currency board period the cyclical volatility of GDP was around 8 percent lower than during the earlier period, though this fall in volatility is not statistically significant. As in the differenced data there is a clear pattern of falls in volatility, with only Singaporean GDP exhibiting greater volatility in the second sub-period (though volatility is lower than in Hong Kong). The falls in the volatility of government expenditure, the real exchange rate, and the Federal Funds rate are all statistically significant. It is interesting that significant falls in volatility of these three factors did not significantly reduce output volatility. Finally, in contrast to the results with the differenced data, oil price volatility is (insignificantly) lower in the filtered data.

The filtered data show some quite different cyclical patterns to the differenced data, though in general correlations with GDP rise in the currency board period whichever filter is used. The size of the government expenditure correlation with GDP is similar to the differenced data in both subsamples, again consistent this variable being acyclical. Both exports and imports again become more procyclical, exports significantly so, in the currency board period. In the filtered data fluctuations in prices change significantly from being mildly procyclical to being acyclical, in contrast to the differenced price (inflation) data. The filtered real exchange rate correlation 
changes markedly, from significantly different from zero and procyclical, to being mildly countercyclical. Here the correlation is consistent with economic theory. Theory suggests that the real exchange rate should be procyclical. Tighter monetary policy during the expansionary phase of the business cycle should see inflation fall, and also put upward pressure on the exchange rate. Empirically this effect is often difficult to pick up, as what really is important is the state of the business cycle in the domestic economy relative to the state of the business cycle in foreign countries. The filtered data does, however, provide evidence of this effect in Hong Kong during the flexible exchange rate period. After the currency board period the real exchange rate does not follow this pattern. This is consistent with monetary policy being determined by economic conditions in the US, rather than in Hong Kong. The filtered Fund rate data shows a significant fall in the correlation with GDP, in contrast with the correlation in growth rates.

Overall Table 1 provides robust evidence regarding the pattern of volatilities during the flexible exchange rate and during the currency board periods, though the evidence regarding cyclical patterns is less consistent across filtering methods. Volatility is generally lower during the currency board era for all of the variables that might affect Hong Kong's output and trade volatility. Foreign monetary shocks, measured by the volatility of the Federal Funds rate, are significantly smaller in the currency board period. Domestic fiscal volatility is also significantly lower during the currency board era. The evidence on oil price volatility is mixed, though it is clear that including the 1974 oil price shock in the sample would lead to the conclusion that this volatility was also lower in the currency board period. Alternately, making the reasonable assumption that the impact on output volatility of oil price shocks lasts at least two 
quarters, the influence of oil price volatility on output volatility is lower in the currency board period. It would be desirable to have a measure of domestic monetary policy over the sample period, but the author has been unable to locate a quarterly monetary aggregate or interest rate variable that would be appropriate over the sample period. While changes in the Fund rate are likely to feed through very strongly to domestic rates and so be a good proxy for domestic monetary policy in the currency board era, no data is presented on monetary policy variability in the floating exchange

rate period. The relevant issue is to what extent was monetary policy variability responsible for the level of output volatility prior to 1983. Jao (1998) argues that monetary policy was very volatile from 1975 to 1983 (annual monetary growth was very high), and that this exacerbated business cycle fluctuations. However, it is difficult to assess the extent to which this volatility differed from monetary and interest rate volatility post 1983 without access to quarterly data.

All of the results so far are based on the univariate properties of the series, most importantly the unconditional variances and means of each of the series. Of course the real issue is the extent to which these variances and means are related, and we now turn to the multivariate evidence on these relationships.

\section{Empirical Results}

There are several different methods available to try and link together the variables and volatilities presented in the previous section. In order to model output volatility a three variable VAR will be estimated, and several pieces of evidence presented. Firstly, the stability of the VAR will be tested. If the VAR is stable, then it would 
appear that there is no evidence that the structure of the Hong Kong economy has changed after the introduction of the currency board. Secondly, the size of the shocks in the output equation will be compared over the two sub-samples, to see if there is evidence of reduced volatility after conditioning on shocks to other variables in the model. Finally, the level and volatility of trade will be related to exchange rate volatility since 1974 .

In estimating a VAR there is a choice between a large model which captures all of the possible forces affecting variables of interest, and a more parsimonious model which uses less degrees of freedom and enables more efficient estimation. Given the aim of estimating the impact of the exchange rate regime on output volatility it is common to choose a small, three or four variable model. Given the available data it is felt that a three variable model including the real oil price, the federal funds rate, and output growth will best describe the output process. The oil price shock should pick up the effect of exogenous real shocks on the Hong Kong economy, while the federal funds rate will pick up the impact of foreign monetary shocks on Hong Kong. During the currency board era the funds rate should also describe the impact of domestic monetary policy on output, because of the link between domestic and foreign monetary policy under a fixed exchange rate. Finally, the output variable will pick up all of the other shocks which affect Hong Kong's GDP. These presumably include monetary, fiscal and any other forces that affect GDP.

The structural model is of the form;

$$
A X_{t}=B(L) X_{t-1}+\varepsilon_{t},
$$


where $X_{t}$ is a vector containing $o_{t}$, the change in the real oil price, $f_{t}$, the change in the federal funds rate, and $y_{t}$, the change in Hong Kong GDP, $A$ is a $3 \times 3$ matrix, $B(L)$ is a matrix polynomial in the lag operator, and $\varepsilon_{\mathrm{t}}$ is a vector containing the three structural shocks $\varepsilon_{\mathrm{t}}{ }^{\mathrm{o}}, \varepsilon_{\mathrm{t}}^{\mathrm{f}}$ and $\varepsilon_{\mathrm{t}}^{\mathrm{y}}$. Premultiplying both sides of (1) by $A$ yields the reduced form equation

$$
X_{t}=\Gamma(L) X_{t-1}+e_{t}
$$

where $\Gamma(L)=A^{-1} B(L)$, and $e_{t}=A^{-1} \varepsilon_{t}$. We can think of the structural shock to $y$ as containing all of the factors that affect Hong Kong GDP other than the (foreign) forces picked up by the two other shock variables. In order to recover the residuals in (1) from the estimated equation (2) some identifying assumptions must be made. Typical identifying assumptions include long run restrictions, restrictions on the matrix $A$, or combinations of these two sets of restrictions. In this paper it seems natural to treat the foreign variables in the model as an exogenous block, and to treat oil as being contemporaneously unaffected by other variables in the model. ${ }^{\square}$ These assumptions enable us to identify the structural residuals from the reduced form residuals given the variable ordering $o, f, y$ in (2).

The preferred model has four lags, and is estimated including a constant. Each variable is entered in first difference form as in (1) and (2), consistent with the unit root evidence outlined in footnote $6 .{ }^{10}$ The first test that is conducted is a stability test for the output equation in the model. A Chow test for a structural break in 1983:4 rejects the null of parameter constancy at any reasonable significance level. The F-test statistic is 14.61 , which has a p-value of less than .01 . If we treat the break date as

\footnotetext{
${ }^{9}$ A more restricted model where the price of oil is treated as an exogenous variable in both of the other equations of the model (restricting the coefficients on all of the variables except lagged oil prices to be zero in the oil equation) leads to very similar results to those presented in this section of the paper.
} 
endogenous, rather than fixed at 1983:4, and search for structural breaks from 1980:1 to $1990: 1$ the F-max statistic is 18.55 in 1982:1. Simulating the model to calculate correct critical values once again leads to rejection of the null of parameter constancy. Hence we can conclude that there is strong evidence of instability in the model, with a structural break occurring around the time of the introduction of the currency board in 1983. We continue under the assumption that two models are required to represent the data, one estimated prior to, and one after 1983.

Table 2 presents the results of causality tests for each equation of the model. In the pre-1984 sample lags of each variable only enter significantly in the own equation of the model. In the output equation the only coefficient that is significant at the five percent level is on the first lag of output. In the latter subsample there are more significant coefficients, and lags of the federal funds rate are helpful in forecasting output. Tests for skewness or excess kurtosis of the residuals in the output equation do not provide evidence against the null in either case, consistent with the residuals being normally distributed. Figure 19 plots the residuals from the output equations estimated over the two subsamples. The figure provides similar evidence to the univariate results presented in the previous section. Shocks to output are significantly smaller since 1983, though much of this reduction in volatility appears to be due to output being very predictable from around 1989 to 1995.

The correlations between the reduced form residuals are less than 0.2 in absolute value in each case in the latter subsample, and less than 0.5 in absoulute value in the earlier subsample, so it seems unlikely that changes in ordering of the variables or in

\footnotetext{
${ }^{10}$ Tests for cointegration do not show any evidence of cointegration among the variables.
} 
identification strategy will affect the conclusions above. Hutchison and Walsh (1992) and Bayoumi and Eichengreen (1994) identified the impact of the exchange rate regime on the domestic economy by examining the shape of the impulse response functions. Figures 20 and 21 show the response of output to unit shocks to the oil price and to the funds rate over each subsample. Figure 20 shows the response of output to a unit shock to the price of oil. The impulse responses are very different, but also contrary to economic theory. In the first sub-sample increases in the price of oil lead to a rise in output growth which persists for at least twenty quarters (refer to impy1), while in the currency board period output initially falls, but rises after ten periods (impy2). While these responses are perverse, simulated two standard error bands (not shown) include zero in both cases. It is also the case that we can drop the oil price variable from the model with no affect on the fit of the output equations. It seems that the oil price variable is simply not doing a very good job at picking up the impact of foreign real shocks on the Hong Kong economy. Shocks to the funds rate do have the effect on output predicted by economic theory. Once again there is a difference between the responses in the currency board period and previously. Prior to 1984 changes in the federal funds rate had no impact on the Hong Kong economy (refer to impy1), while since 1984 US monetary tightenings have had a significant effect on Hong Kong's GDP growth two to three years after such tightenings (again according to the simulated confidence intervals). This is consistent with the idea that flexible exchange rates do allow an economy to insulate against foreign monetary shocks.

In order to examine the impact of exchange rate volatility on the trade variables some simple graphical techniques along the lines of Flood and Rose (1995) are presented. 
Figures 22 and 23 show the variance of the exchange rate in each non-overlapping two year interval from 1974 to 1999, along with the mean growth in real exports or imports for the subsequent two year period (graphs of contemporaneous growth look similar). The graphs show no obvious pattern, and the correlations between exchange rate volatility and the trade variables are not significantly different from zero. Though this technique is admittedly simple, it leads us to the conclusion that the periods of greater real exchange rate volatility in Hong Kong are not followed by periods of any lower or higher growth in trade. If we replace the mean growth rate of the trade variables with the variance of these growth rates the same conclusion is reached.

\section{Conclusions}

In this paper the evidence on whether Hong Kong's currency board arrangement affects real macroeconomic volatility has been examined. Overall there is evidence that the currency board period has been one of relatively low volatility in Hong Kong. The low volatility has coincided with a benign external environment, though after controlling for the level of external volatility it is still concluded that volatility is lower than expected since 1983. Can we conclude that the reduction in volatility has been caused by the change in the exchange rate regime in 1983 ? There seem to be two issues that need further exploration before this conclusion could confidently be made. Firstly, to what extent has the currency board arrangement reduced real exchange rate volatility? The estimates in this paper suggest that the CPI based real exchange rate has seen a fall in volatility of the order of eight percent. It would be desirable to measure volatility using other methods and exchange rate data than have been used in this paper to check the robustness of this conclusion. Secondly, why did the reduction 
in volatility appear to occur several years after the introduction of the currency board? Growth was very stable in Hong Kong from around 1989 until the Asian crisis, and perhaps some factor not explored in this paper can account for this stability. I have explored, with no success, two alternative explanations for this stability. One possibility, consistent with the idea that Hong Kong's industrialisation process has delivered more stable output, is that the change from a manufacturing to a more services based economy leads naturally to greater stability. To test this hypothesis I examined the annual variability in manufacturing and in financing, insurance, real estate and business services, since 1980. While it is true that the importance of manufacturing has steadily declined over this period from around $22 \%$ to around $6 \%$ of GDP, the variance of the growth in manufacturing is actually less than the variance in services growth. Hence it would not appear that the move away from a manufacturing based economy is the cause of the stability of output. Relatedly, the share of government in GDP has not changed, so the stability in the 1990s cannot be attributed to a rising share of a less volatile government sector in the economy. A second possibility is that the stability in Hong Kong is related to more stable economic growth in China. Because of the importance of re-exports to the Hong Kong economy, growth in China is very important to Hong Kong's economic performance. Perhaps stable growth in China is responsible for stability in Hong Kong? Again it would seem not. The annual real GDP data for China that is available since 1980 does not suggest any reduced volatility in the 1990s.

Is it possible to argue the case more strongly for or against a currency board in Hong Kong on the basis of the evidence in this paper? The answer to this question will depend on a more full blown account of the impact of the exchange rate regime on the 
growth rates of the variables studied, as well as considering just the volatilities. The evidence in this paper does, however, provide support for the idea that a currency board is able to reduce volatility in the real economy, as well as in the real exchange rate. 


\section{References}

Arize, A., T. Osango and D. Slottje (2000) "Exchange rate volatility and foreign trade: evidence from thirteen LDCs," Journal of Business and Economic Statistics, 18, 10-17.

Baxter, M. and A. Stockman, (1989) "Business Cycles and the Exchange Rate Regime," Journal of Monetary Economics, 23, 337-400.

Bayoumi, T. and B. Eichengreen, (1994) "Macroeconomic Adjustment under BrettonWoods and the Post-Bretton-Woods Float: An Impulse Response Analysis," The Economic Journal, 104, 813-827.

Blanchard, O., and D. Quah (1989) "The dynamic effects of aggregate demand and supply disturbances," American Economic Review, 79, 655-673.

Côté, A. (1994) "Exchange Rate Volatility and Trade: A Survey," Bank of Canada Working Paper 94-5.

Flood, R. and A. Rose, (1995) "Fixing exchange rates: A virtual quest for fundamentals," Journal of Monetary Economics, 36, 3-38.

Frankel, J. (1999) "No Single Currency Regime is Right for all Countries at all Times,” NBER Working Paper 7338.

Frankel, J. and A. Rose, (1995) "Empirical Research on Nominal Exchange Rates," Chapter 33 in The Handbook of International Economics, Volume 3, edited by G. Grossman and K. Rogoff, North-Holland.

Froot, K., and K. Rogoff (1995), "Perspectives on PPP and Long-Run Real Exchange Rates," Chapter 32 in The Handbook of International Economics, Volume 3, edited by G. Grossman and K. Rogoff, North-Holland.

Gagnon, J. (1993) "Exchange rate variability and the level of international trade," Journal of International Economics, 34, 269-287.

Hutchison, M. and C. Walsh, (1992) "Empirical evidence on the insulation properties of fixed and flexible exchange rates: the Japanese experience," Journal of International Economics, 32, 241-263.

IMF (1999) "People's Republic of China - Hong Kong Special Administrative Region: Recent Economic Developments.” IMF Staff Country Report 99/34. Available at the IMF's website, Www.imf.org

Jao, Y. (1998) "The Working of the Currency Board: The Experience of Hong Kong 1935-1997," Pacific Economic Review, 3, 219-241.

Kwan, Y., and F. Lui (1999) "How well has the Currency Board Performed? Evidence from Hong Kong," mimeo, Hong Kong University of Science and Technology. 
Rose, A., (1996) "After the Deluge: Do Fixed Exchange Rates Allow Intertemporal Volatility Tradeoffs?" International Journal of Finance and Economics, 1, 47-54.

Rose, A. (1999) "One Money, One Market: Estimating the Effect of Common Currencies on Trade," NBER Working Paper 7432.

Zanello, A., and D. Desruelle, (1997) "A Primer on the IMF's Information Notice System," Working Paper 97/71, International Monetary Fund. 
Table 1: Volatilities and Correlations.

Differenced Data

\begin{tabular}{|c|c|c|c|c|c|c|}
\hline \multirow[b]{2}{*}{ Variable } & \multicolumn{3}{|c|}{ 1974:4-1983:3 } & \multicolumn{3}{|c|}{ 1984:1-1999:4 } \\
\hline & $\bar{x}$ & $\sigma$ & $\rho$ & $\bar{x}$ & $\sigma$ & $\rho$ \\
\hline$\Delta \mathrm{GGDP}$ & 7.6 & 2.61 & 1.00 & 5.0 & $1.59^{*}$ & 1.00 \\
\hline$\Delta$ Gov. Exp. & 8.9 & 1.97 & -0.10 & $4.3^{*}$ & $1.00^{*}$ & $0.20^{*}$ \\
\hline$\Delta$ Exports & 9.1 & 4.75 & 0.59 & 10.5 & $3.04^{*}$ & 0.64 \\
\hline$\Delta$ Imports & 12.5 & 5.83 & -0.09 & 10.8 & $3.51^{*}$ & $0.42^{*}$ \\
\hline Inflation & 8.3 & 1.27 & -0.23 & $6.0^{*}$ & 1.04 & $0.10^{*}$ \\
\hline$\Delta$ Inflation & 0.1 & 1.08 & -0.32 & -0.3 & $0.55^{*}$ & 0.01 \\
\hline$\Delta$ Real exch. & -2.9 & 3.21 & 0.00 & $2.8^{*}$ & 2.92 & -0.02 \\
\hline$\Delta$ Funds Rate & -0.3 & 2.51 & -0.31 & -0.3 & $0.68^{*}$ & $0.21^{*}$ \\
\hline$\Delta$ Oil & 14.1 & 14.22 & 0.09 & -2.9 & $21.38^{*}$ & 0.08 \\
\hline$\Delta$ Sing. GDP & 8.1 & 0.95 & -0.18 & 6.9 & 1.87 & $0.19^{*}$ \\
\hline \multicolumn{7}{|c|}{ Band Pass Filtered Data } \\
\hline GDP & & 3.23 & 1.00 & & 2.98 & 1.00 \\
\hline Govt. Exp. & & 2.89 & 0.04 & & $1.56^{*}$ & 0.24 \\
\hline Exports & & 5.69 & 0.74 & & 4.90 & $0.89^{*}$ \\
\hline Imports & & 6.70 & 0.75 & & 5.30 & 0.84 \\
\hline $\mathrm{CPI}$ & & 2.40 & 0.24 & & 1.99 & $-0.07^{*}$ \\
\hline Real exch. & & 4.73 & 0.36 & & $3.61^{*}$ & $-0.15^{*}$ \\
\hline Funds Rate & & 2.07 & 0.50 & & $0.99^{*}$ & $0.08^{*}$ \\
\hline Oil & & 18.58 & 0.17 & & 17.53 & 0.23 \\
\hline Sing. GDP & & 1.29 & 0.59 & & $2.75^{*}$ & 0.43 \\
\hline
\end{tabular}

Notes to Table: $\bar{x}$ is the mean annualised growth rate for each variable, $\sigma$ is the standard deviation of the differenced or filtered series, and $\rho$ is the correlation with GDP. A * indicates that the mean, standard deviation or the correlation is significantly different from the standard deviation or correlation in the earlier subsample, at the five percent significance level (the null hypothesis relies on the assumption of independent samples). 
Table 2: VAR estimates

\begin{tabular}{|c|c|c|c|c|c|c|c|}
\hline \multicolumn{8}{|c|}{ Model: $A(L) X_{t}=B(L) X_{t-1}+\varepsilon_{t}$} \\
\hline & \multirow[t]{2}{*}{ Equation } & \multicolumn{2}{|c|}{ OIL } & \multicolumn{2}{|c|}{ FUNDS RATE } & \multicolumn{2}{|c|}{ HK GDP } \\
\hline & & F-stat. & p-value & F-stat. & p-value & F-stat. & $\mathrm{p}$-value \\
\hline F-test & oil $\rightarrow$ & 7.45 & 0.00 & 0.30 & 0.87 & 0.81 & 0.53 \\
\hline \multirow[t]{2}{*}{$1974-83$} & funds $\rightarrow$ & 0.41 & 0.80 & 5.64 & 0.00 & 1.03 & 0.41 \\
\hline & hkgdp $\rightarrow$ & 0.89 & 0.49 & 1.41 & 0.26 & 88.88 & $\mathbf{0 . 0 0}$ \\
\hline F-test & oil $\rightarrow$ & 7.50 & 0.00 & 0.71 & 0.59 & 0.41 & 0.81 \\
\hline \multirow[t]{2}{*}{ 1984-99 } & funds $\rightarrow$ & 1.48 & 0.22 & 59.62 & 0.00 & 4.46 & 0.00 \\
\hline & hkgdp $\rightarrow$ & 1.70 & 0.16 & 0.89 & 0.48 & 1511.50 & 0.00 \\
\hline \multirow{2}{*}{\multicolumn{4}{|c|}{$\begin{array}{l}\text { Test for skewness (null = no skewness) } \\
\text { Test for kurtosis (null = no kurtosis) }\end{array}$}} & \multirow{2}{*}{\multicolumn{2}{|c|}{ 1974:3-1983:4 }} & & 0.63 \\
\hline & & & & & & & 0.50 \\
\hline \multirow{2}{*}{\multicolumn{4}{|c|}{$\begin{array}{l}\text { Test for skewness (null = no skewness) } \\
\text { Test for kurtosis (null = no kurtosis) }\end{array}$}} & \multirow{2}{*}{\multicolumn{2}{|c|}{ 1983:4-1999:4 }} & & 0.60 \\
\hline & & & & & & & 0.95 \\
\hline
\end{tabular}

Notes to Table: The cell values represent the results from F-tests of the hypothesis that the coefficients on the lagged row variables are zero in the column equation. The standard error of the estimate in the output equation was .0225 from 1974:3-1983:4 and .0131 in the 1983:4-1999:4 subsample. 
Figure 1: Hong Kong GDP growth

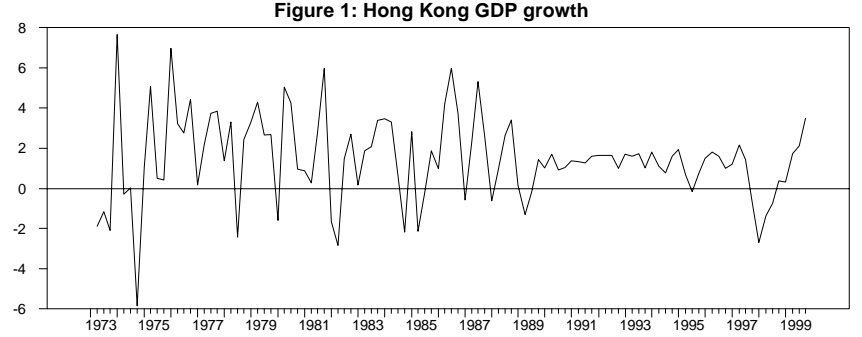

Figure 3: Export growth

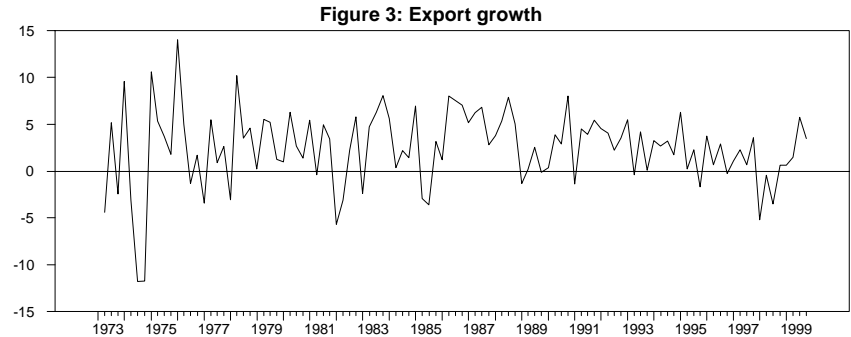

Figure 5: Inflation

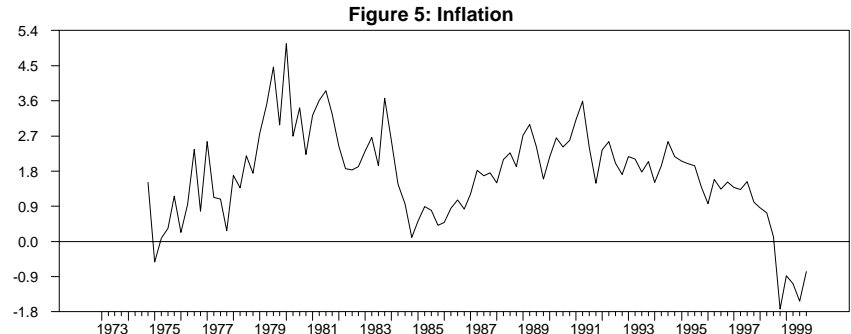

Figure 7: Change in real \$HK Oil price

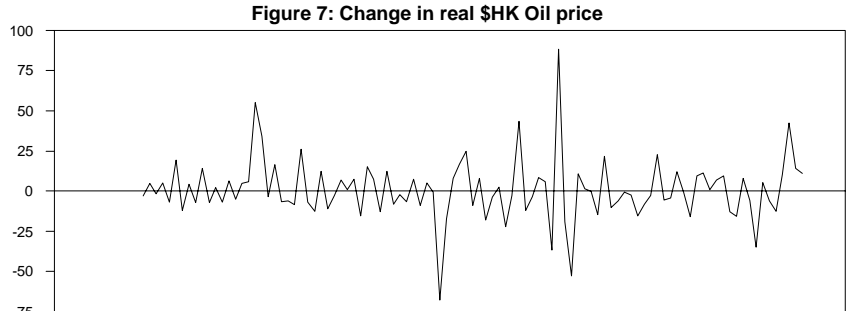

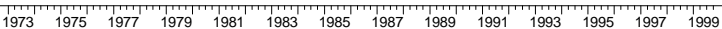

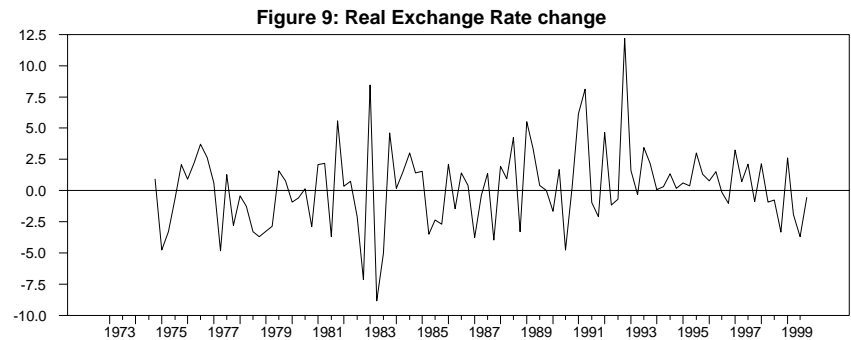

Figure 2: Government Expenditure growth

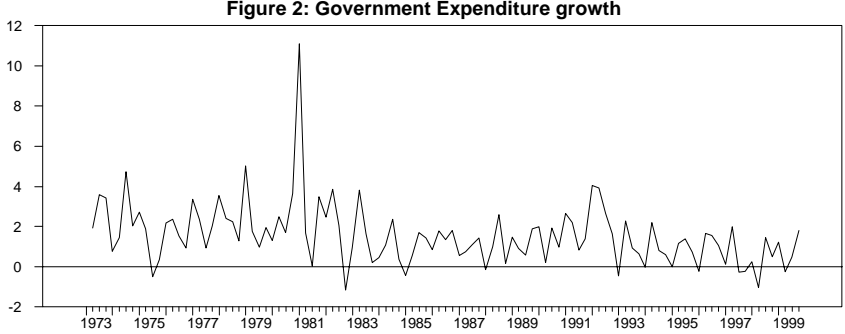

Figure 4: Import growth

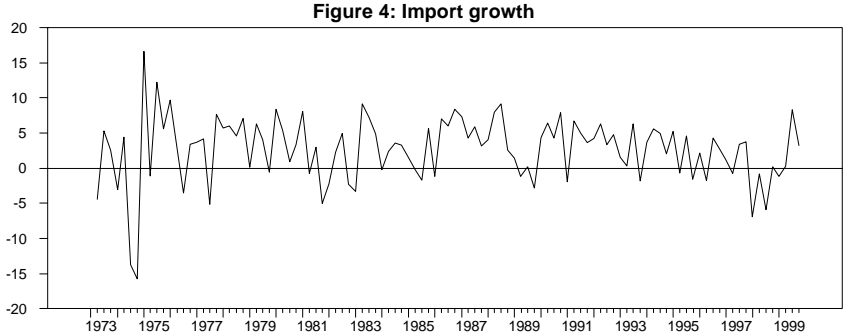

Figure 6: Change in Inflation

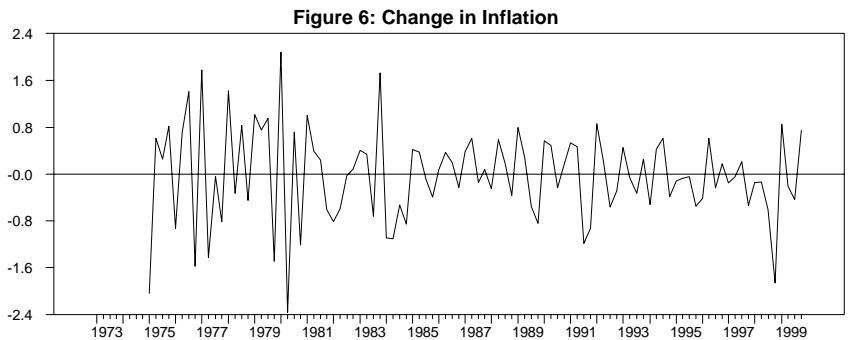

Figure 8: Change in Federal Funds Rate

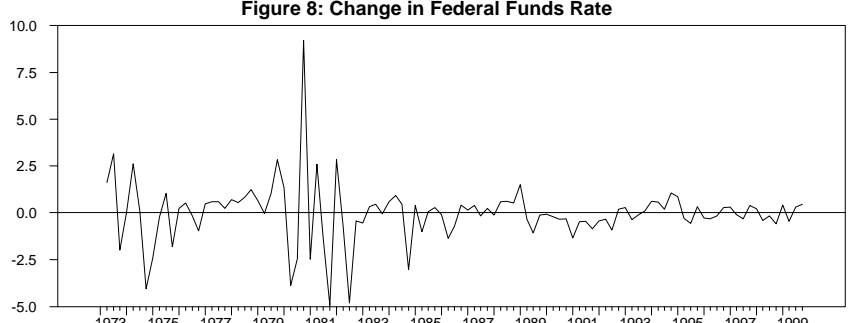

Figure 10: Singaporean GDP growth

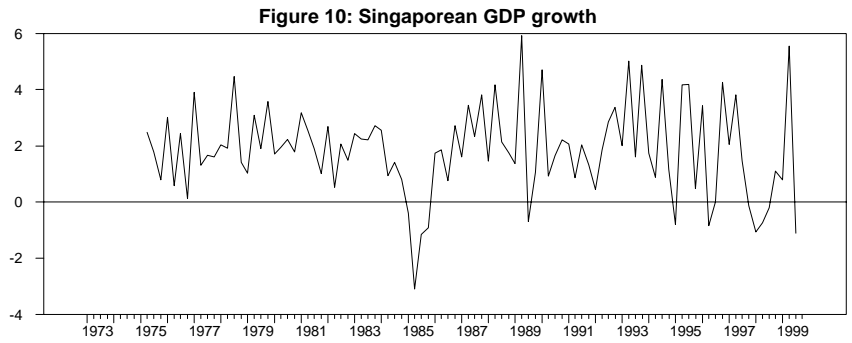


Figure 11: GDP and Government Consumption

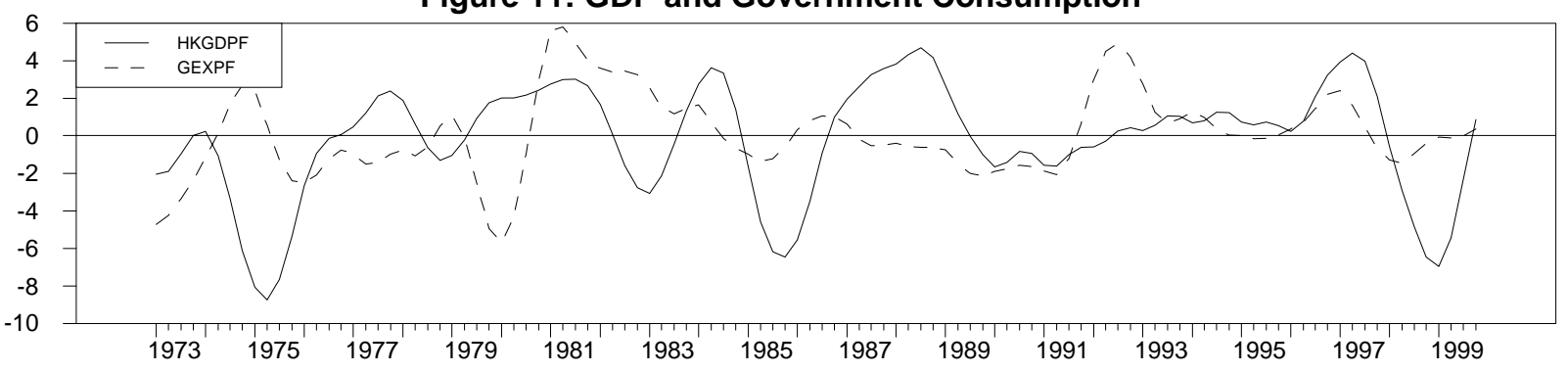

Figure 12: GDP and Exports

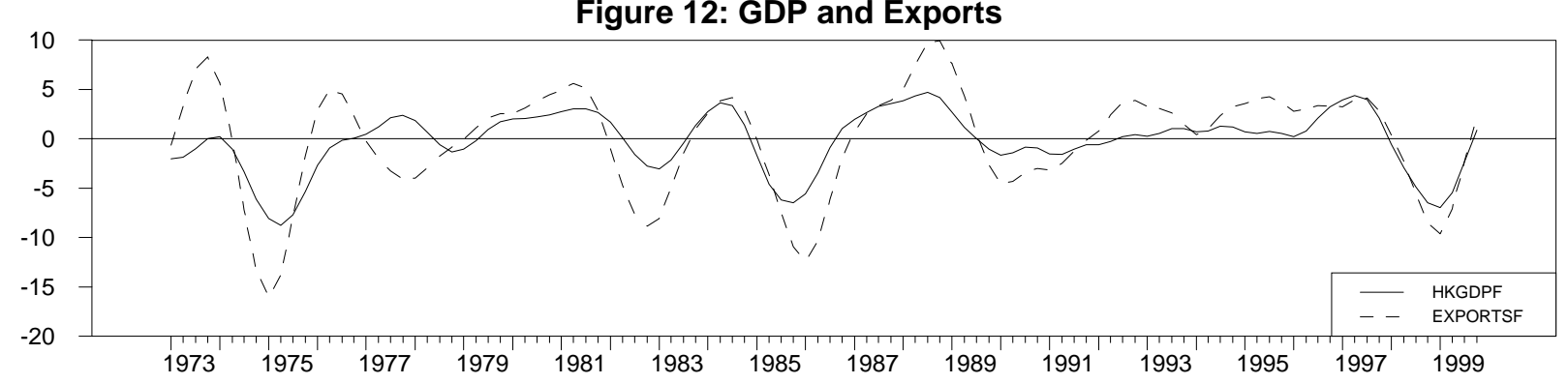

Figure 13: GDP and Imports

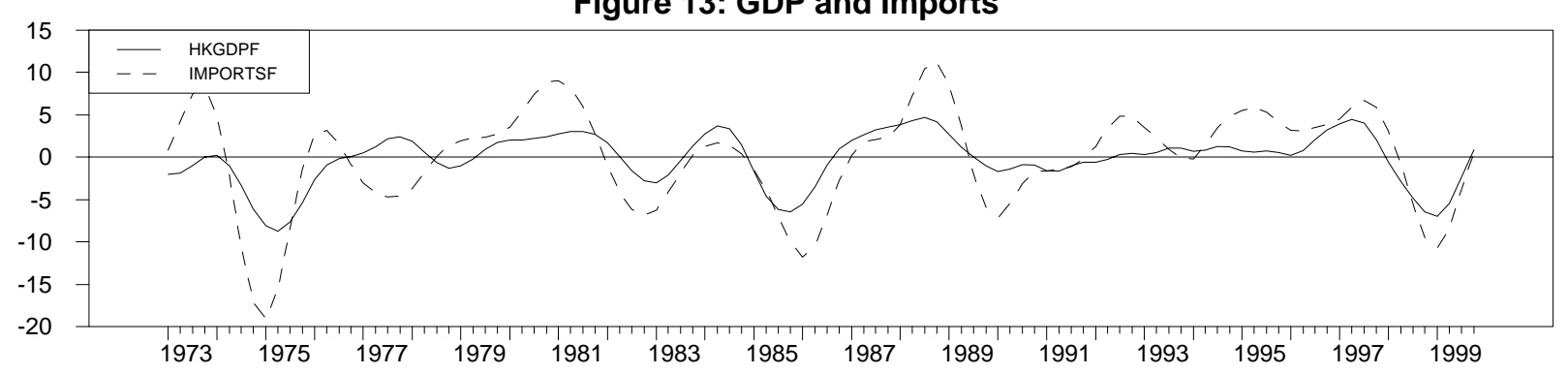

Figure 14: GDP and Prices

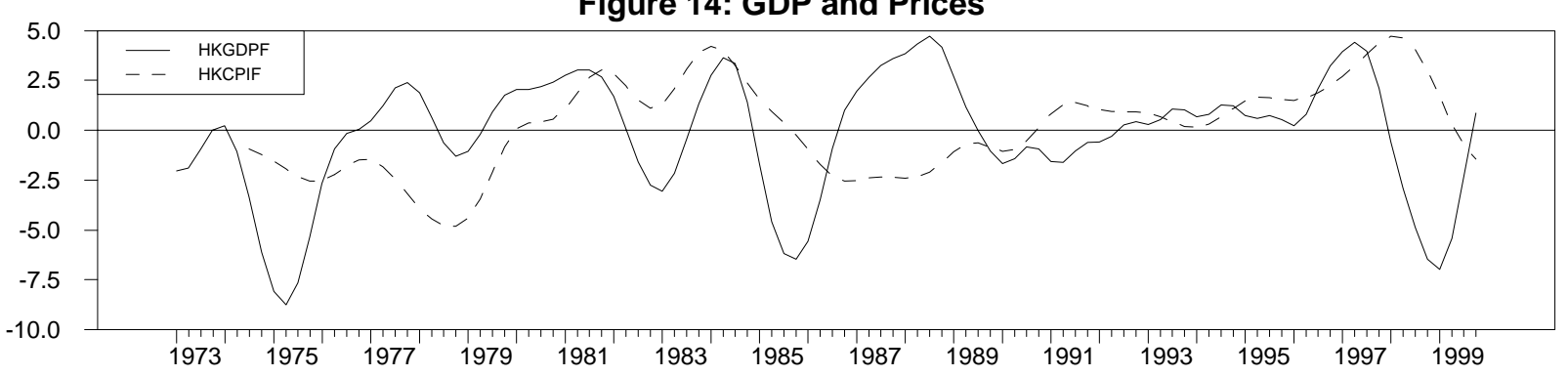


Figure 15: GDP and the real Exchange Rate

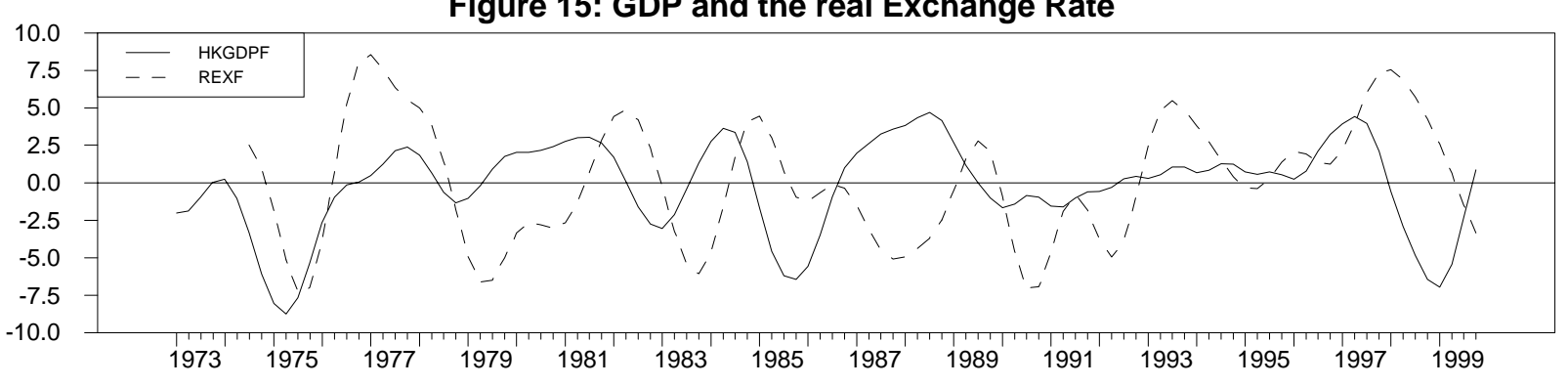

Figure 16: GDP and the US Federal Funds Rate

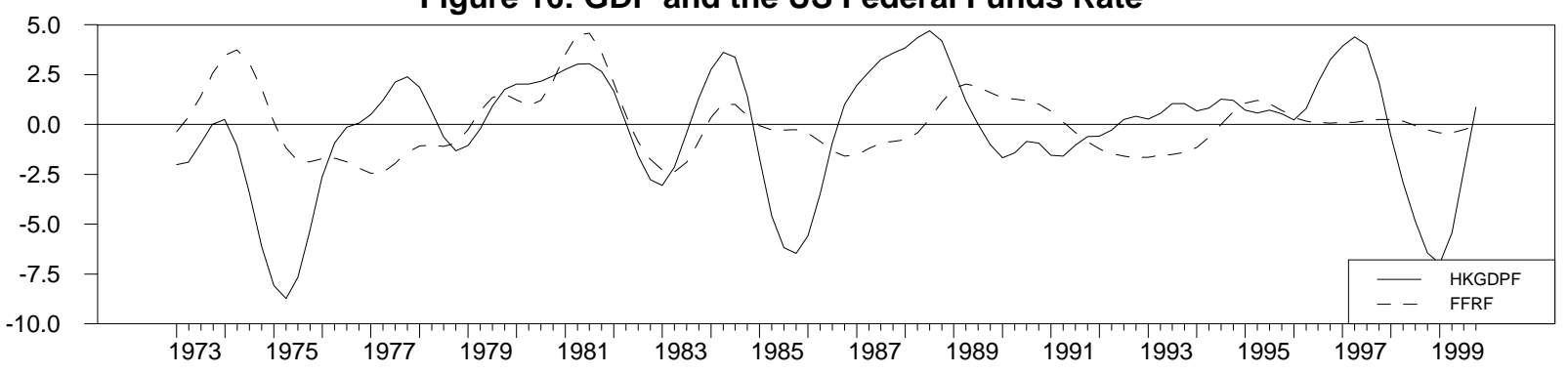

Figure 17: GDP and real oil prices

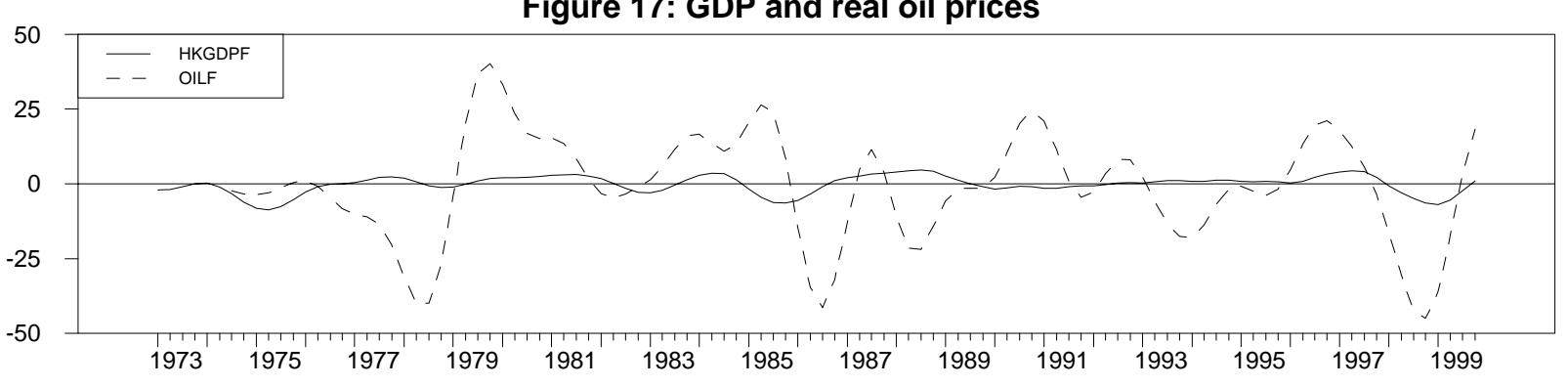

Figure 18: Hong Kong GDP and Singaporean GDP

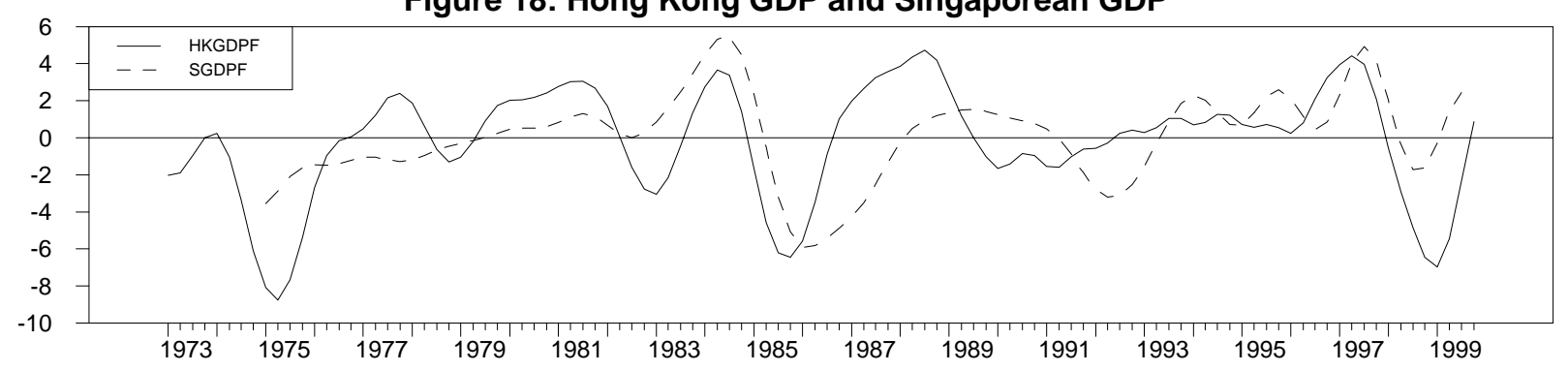


Figure 19: Residuals from two sub-sample output equations
0.050

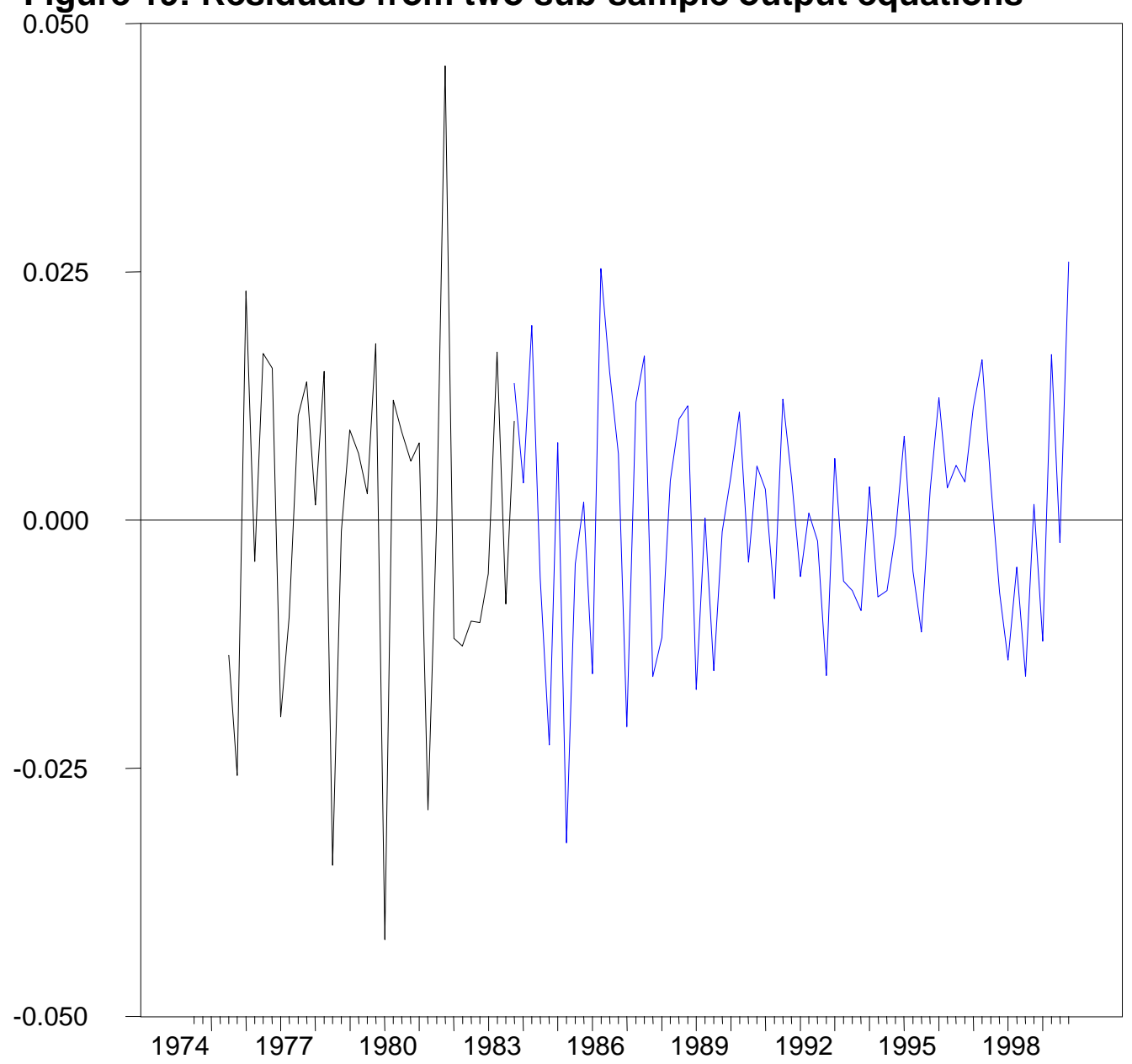




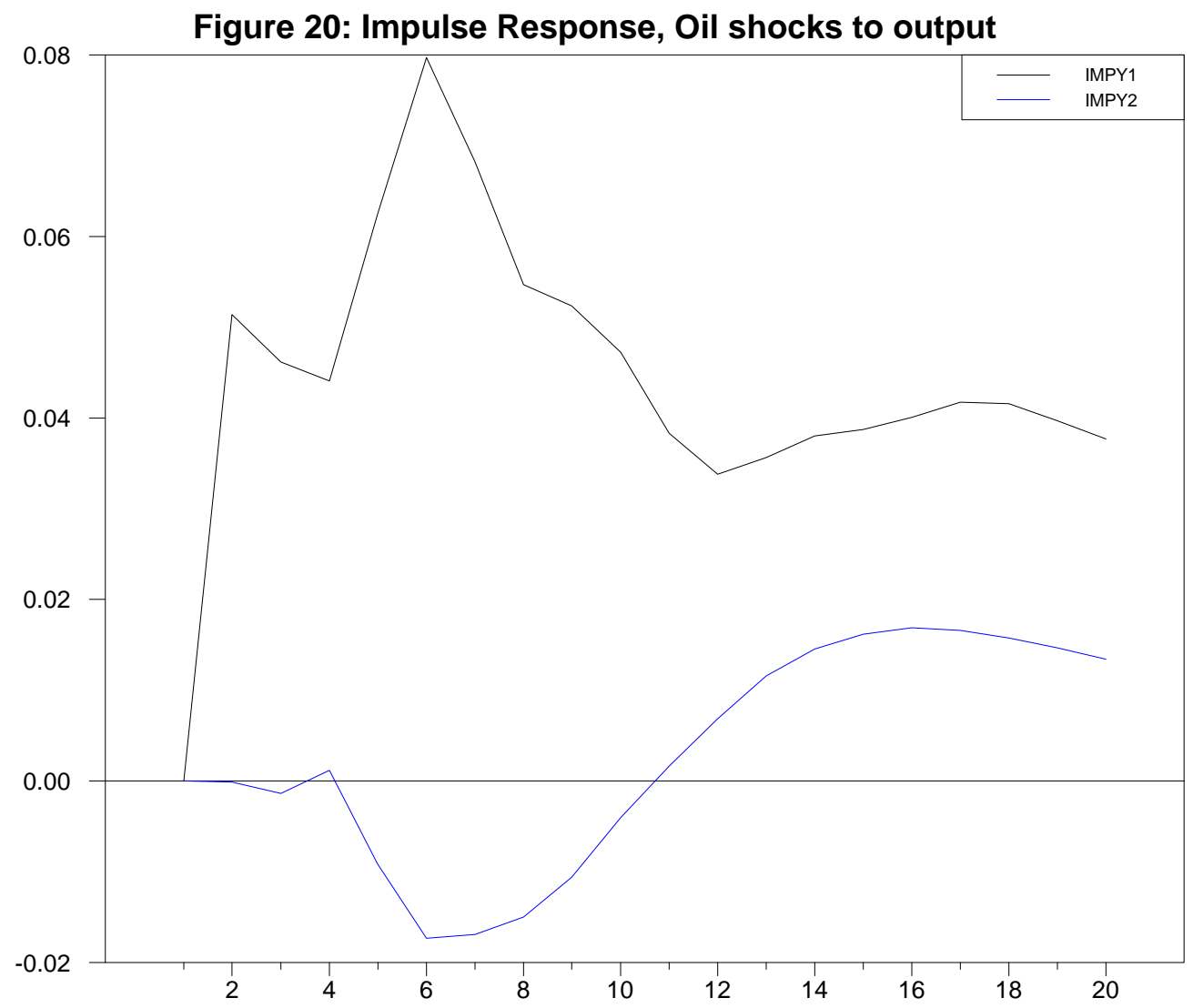




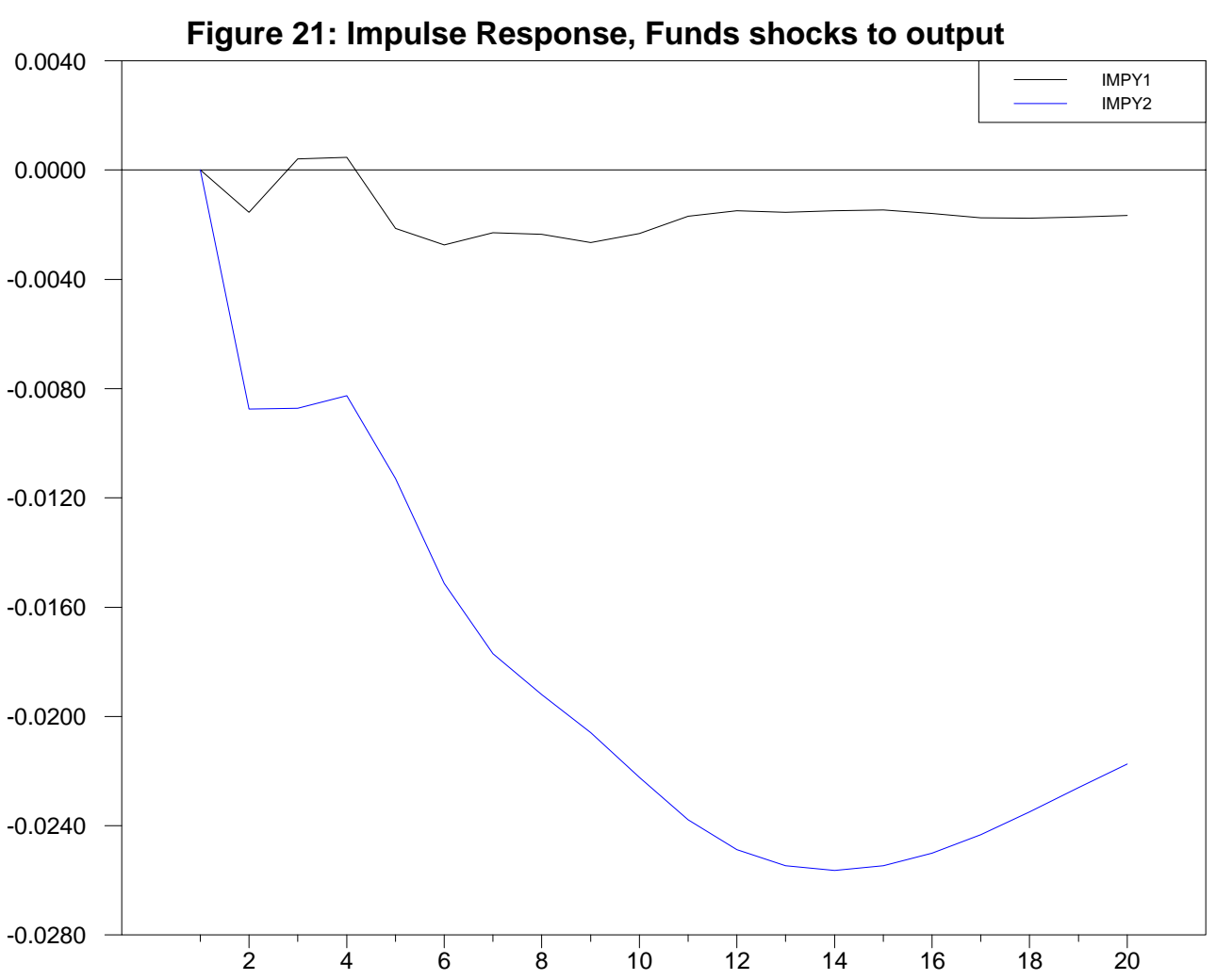


Figure 22: Export Growth (2 year lead) and Exchange Rate Variance

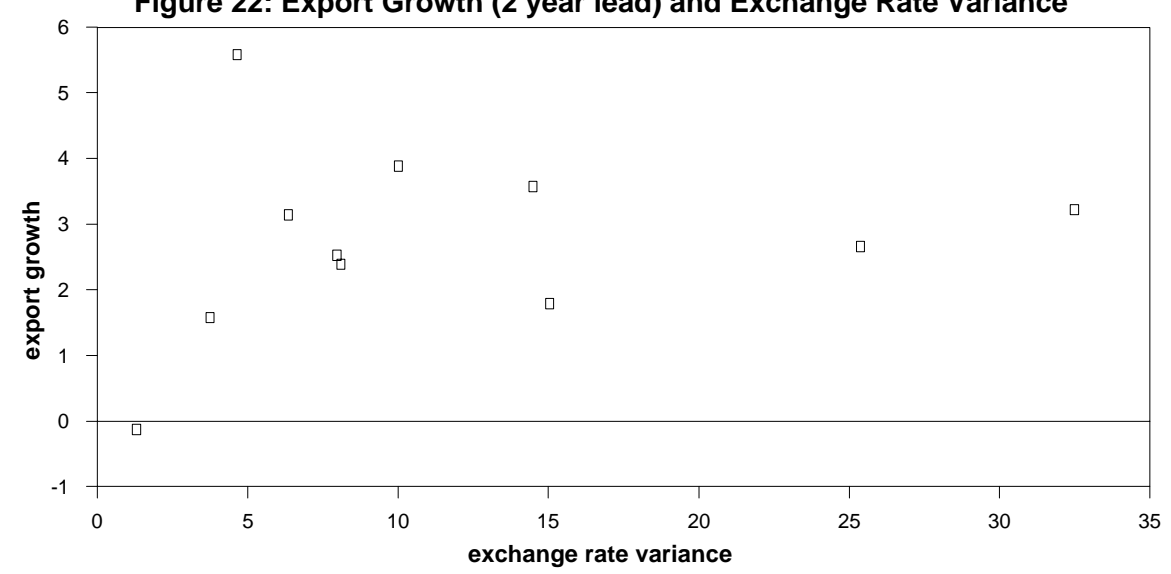

Figure 23: Import Growth (2 year lead) and Exchange Rate Variance

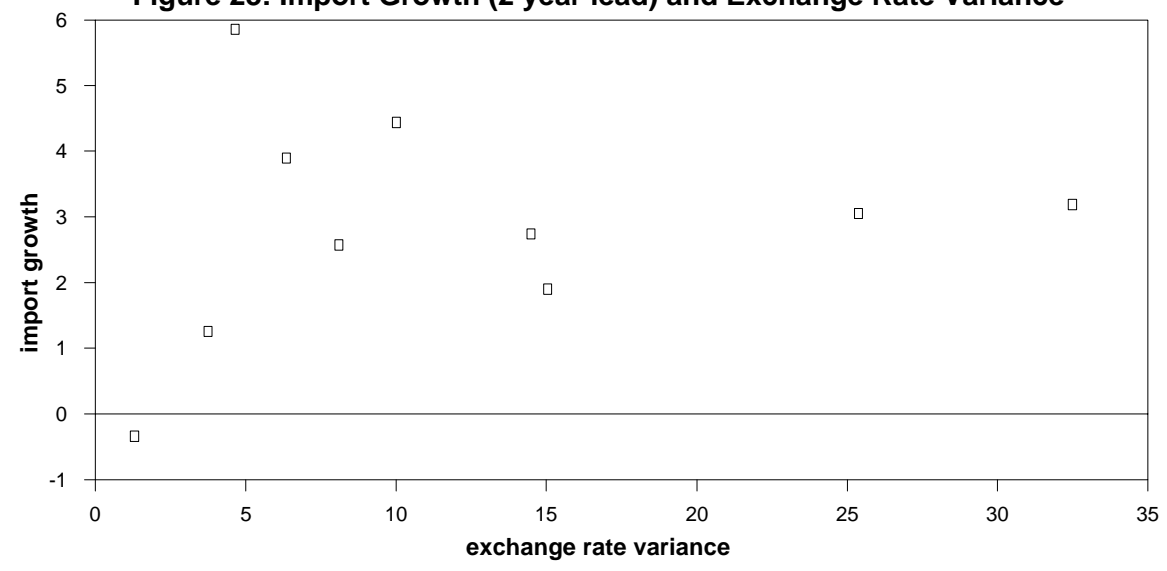




\section{University Library}

\section{- M M I E E R VA A gateway to Melbourne's research publications}

Minerva Access is the Institutional Repository of The University of Melbourne

Author/s:

CROSBY, MARK

Title:

Exchange rate volatility and macroeconomic performance in Hong Kong

Date:

2000-05

Citation:

Crosby, Mark (2000) Exchange rate volatility and macroeconomic performance in Hong Kong .

Persistent Link:

http://hdl.handle.net/11343/33650 